\title{
A Study of Contract Broiler Production in Lombok, NTB: An Opportunity of Introducing Syariah Partnership
}

\author{
B. Indarsih*, M. H. Tamsil, \& M. P. Nugroho \\ Department of Animal Production, Faculty of Animal Science, Mataram University \\ Jln. Majapahit No. 62 Mataram, Lombok, Nusa Tenggara Barat \\ (Received 12-01-2010; accepted 04-08-2010)
}

\begin{abstract}
A study to evaluate the implementation of integrated poultry production through contract farming system in Lombok, NTB was carried out from June to November 2009. The descriptive methods were used whilst the data was collected using survey methods. Fifty contract farmers were selected to measure the business performance with references on management, performance production index, FCR, and percentage of mortality. The results of this study indicated that the contract broiler production was chosen due to: (1) risk sharing $(27.6 \%)$, financial credits $(25.8 \%)$, and the guarantee of marketing ( $23.3 \%)$. Dissatisfaction particularly in aspects of incentive determination, the quota, and margins. The margin ratios between farmers and integrators, $30 \%: 70 \% ; 40 \%: 60 \%$ or $50 \%: 50 \%$ with no clear reasons. Performance parameter was as an expectation, suggesting feed quality and management aspects were well implemented. In respect to Syariah bank, its outstanding was well understood but it have not been attractive to the contract farmers. The capital is not the main reason to work with the integrators. The government involvement was needed to encourage poultry industry growth and looking for the new potential region and legislation on maintaining environment. New investors should be encouraged to overcome instability price.
\end{abstract}

Key words: contract system, farmers, efficiency index, margin ratios

\section{INTRODUCTION}

Commercial poultry sectors, which started in 1980s, have not met the need for animal protein in the province of Nusa Tenggara Barat (NTB). This can be shown by the fact that the protein consumption in this province was approximately $56.5 \mathrm{~g} / \mathrm{cap} / \mathrm{d}$, which was most from non animal protein (BKP, 2008). This means that efforts need to be done to support the growth of animal protein sources.

The dominance of small farmers in Indonesian Agriculture business has resulted in various risks and uncertainties at the marketing stage. After economic crisis in 1998, there was a significant change in the model farming from non-contract to contract farmers in efforts to solve the uncertainties and marketing power which the individual farmer have no this power. The number of scientific works relating to an analysis of the contract farming has revealed that contract farmers were advantageous over the non-contract (independent)

\footnotetext{
* Corresponding author:

Department of Animal Production, Faculty of Animal Science,

Mataram University

Jln. Majapahit No. 62 Mataram, Lombok, Nusa Tenggara Barat

e-mail: budiindarsih@gmail.com
}

and /or contract poultry shop (Tatlidil \& Aktũrk, 2004; Begum, 2005; Goodwin et al., 2005; Simmons et al., 2005). A study in Deli Serdang by Siagian (2001) suggested that contract farming-PIR (Pola Inti Rakyat), offers several potential advantages such as able to increase the poultry production and reduce feed cost which leads to increase the farmer income. Also reported by Priyono et al. (2004) that there was positive relationship between farmer's net incomes with farm size.

However, in many cases, farmers highlighted the condition where they received unexpected hopes. Low quality feed and the day-old-chicks (doc), uncertainty in marketing time and unfair bonus payments are frequently met. In other words, there is the inequality of the relationship and the stronger position of integrators with respect to that of farmers. Contract farming is viewed as essentially benefiting integrators by enabling them to obtain cheap labor and to transfer risks to farmers (Eaton \& Shepherd, 2001). Thus, it could be possible to introduce a new concept of partnership "Syariah" as suggested by Sutawi (2006).

Dozier et al. (2008) reported that live performance of broilers from 1 to $35 \mathrm{~d}$ of age was $1910 \mathrm{~g}$ body weight (BW) with feed conversion ratio (FCR) 1.47 and $2798 \mathrm{~g}$ cumulative feed intake (FI) when high amino acid density was fed. Reported by Schmidt (2008) that the increase 
in density in $1.0 \mathrm{bird} / \mathrm{m}^{2}$ resulted in worse FCR and carcass yield (CY), in 0.03 units and $0.81 \mathrm{~g}$, respectively. Reduced average flock weight (AFW), daily weight gain (DWG), and PEI in $17.5 \mathrm{~g}, 0.70 \mathrm{~g}$, and 5.8 units, respectively were recorded due to high density housing. Data of Aftab (2009) suggested that high metabolizable energy $(2850 \mathrm{kcal})$ with balanced protein $(206 \mathrm{~g} / \mathrm{kg} \mathrm{CP}$ and $10.2 \mathrm{~g}$ lysine expressed as standardized ileal digestibility lysine per $\mathrm{kg}$ ) resulted in higher BW at $35 \mathrm{~d}$ of age (1694 g) than $2750 \mathrm{kcal}$ or $2650 \mathrm{kcal}$ (1665 or $1612 \mathrm{~g}$ ). Thus, the quality feed will be reflected in efficient performance and together with other management aspects such as housing capacity affected the final bird performance.

Although there is a conflict in its implementation, poultry agribusiness is still regarded as a potential regional income for the government and protein supply for low income people. In encouraging the poultry development in Lombok, NTB, the current study aims to give a picture of the reality on the implementation of the contract farmers from the farmer's point of view with references on performance parameters, margin and motivating factors. Therefore, an appropriate strategy for the further development in this region can clearly be proposed and Syariah partnership as a new concept is also introduced as a possible alternative to solve the relevant problems.

\section{METHODS}

The primary data was collected from broiler growing farms by contract farming model through interviews to farmer's representatives of West, Central and East Lombok covering from June to November 2009 production period. A sample size of 50 farms was chosen for the study.

The profitability level of the production activity at marketing age (MA) of broilers was proposed as the determinant of success in broiler production. Performance efficiency index (PEI) was calculated as the determinant of success in management operation by considering mortality rate (M), body weight (BW) and FCR. SWOT analysis was also used to give the possibility to define prerequisites and directions for the future development (Çinar et al., 2003).

Performance parameters such as FCR, PEI, and M, were measured with the following calculation:

FCR : FI/BW

PEI : $(100 \%-M \times B W \times 100) / M A \times F C R$

$\mathrm{M} \quad$ : $(\mathrm{TD}-\mathrm{TB}) / \mathrm{TD} \times 100 \%$

where TD is total doc (day old chicks) whilst TB is total bird at marketing age. Other relevant parameters were bird density and rearing period. Samples of commercial feed used by the farmers were taken for chemical analysis. The gross income was calculated on the basis of the total income from selling the live birds deducted by variable costs (feed, doc, medication, labor, and operational). Tabular analysis was also adopted to analyze the cost and revenue variability of broiler farming.

\section{RESULTS AND DISCUSSION}

\section{General View of Contract Implementation of Broiler Operations}

There were two main integrators as representative of large firms in West Nusa Tenggara dominating the poultry business: PT Ciomas Adisatwa (PT. Japfa Comfeed Indonesia) and PT. Mitra Sinar Jaya (PT. Charoen Pokphand Indonesia). Both firms had their own role and designed contract even though the objectives were similar.

Some criteria's were imposed to the farmers: (1) the availability of land for housing which technically meeting the acceptable design, (2) have access to the main road for car/trucks as a transporting vehicle and electricity also available, (3) farmers able to show the valid identity (KTP), and (4) Farmers should have a map showing the farm location. The significant difference between the two firms in implementing the contracts was that there was no support provided to farmers apart from the provision of foundation by PT. Mitra Sinar Jaya whereas PT. Ciomas Adisatwa also provided a credit to purchase operational inputs such as a litter or fuel. In other words, the costs for some items can be the responsibility of either party or they can be shared.

There were two payment schemes consisting of a fixed base payment per $\mathrm{kg}$ of live weight and the variable bonus payment based on the farmer's relative performance. The bonus payment is determined as a percentage of the difference between group -average settlement costs and producer's individual settlement costs. However, the fixed base payment is implemented, and the second scheme was neglected. Most of farmers did not know much about the scheme. Responses of the farmers on the implementation of the contract farmer were quite good, although integrators have a superior ability over the farmers.

\section{Contract Farmers}

Summary information on characteristics of contract farmers is shown in Table 1, whilst average broiler contract operation characteristics are presented in Table 2. In general, farmers chosen as a sample were $20-70$ years of age with average $44.2 \pm 10.5$ years. About $48.0 \%$ of the respondent was dominated by the age between $41-50$ years. Experience in broiler farming was $6.2 \pm 3.2$ years. Educational background of respondents was occupied by high school most (Figure 1).

As shown in Table 2, the average farm size of contract farmers was dominated by $2.500-5.000$ birds $(42 \%)$ with a good livability for more than $95 \%$. Gross income was between Rp2.782.500-89.050.100 with average Rp36.265.706 \pm 21.535 .057 (data not shown). A large number of contract broiler farmers studied recently expressed satisfaction with their contract arrangements, including their income and the rate of return on invested capital, many farmers expressed dissatisfaction with bonus determination, communication, and a number of other operational issues with their contractor. This present study is similar to data reported by Patrick (2004) 
Table 1. Characteristics of broiler contract farmers in Lombok, NTB, June-November 2009 ( $\mathrm{n}=50)$

\begin{tabular}{lcc}
\hline \multicolumn{1}{c}{ Entry } & $\begin{array}{c}\text { No of } \\
\text { respondent }\end{array}$ & $\%$ \\
\hline Age (years) & 6 & 12 \\
$20-30$ & 12 & 24 \\
$31-40$ & 24 & 48 \\
$41-50$ & 8 & 16 \\
$>50$ & 35 & 70 \\
Main occupation as farmer & 15 & 30 \\
Secondary occupation & & \\
Experience in broiler farming & & \\
(years) & 26 & 52 \\
0-5.0 & 19 & 38 \\
5.1-10 & 5 & 10 \\
$>10$ &
\end{tabular}

Source: Primary data analysis

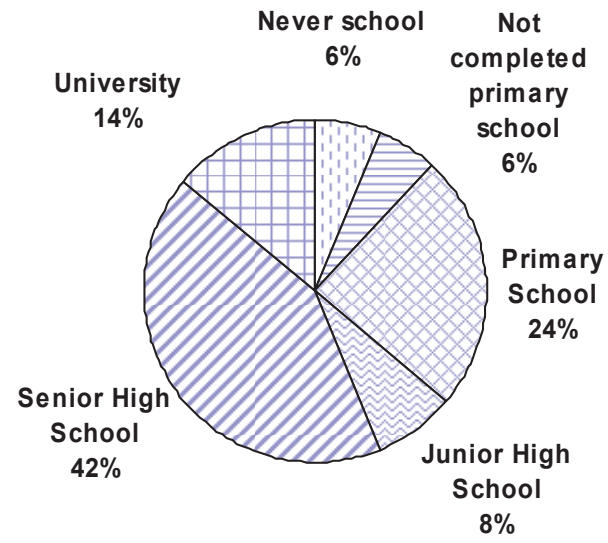

Figure 1. Educational background of broiler contract respondents in Lombok, NTB, June-November 2009 ( $\mathrm{n}=50)$

Table 2. Average broiler contract operation characteristic in Lombok, NTB, June-November $2009(n=50)$

\begin{tabular}{lcc}
\hline \multicolumn{1}{c}{ Description } & $\begin{array}{c}\text { No of } \\
\text { respondent }\end{array}$ & $\%$ \\
\hline $\begin{array}{l}\text { Housing capacity (bird) } \\
\quad<2500\end{array}$ & 17 & 34 \\
$\quad 2,500-5,000$ & 21 & 42 \\
$\quad>5,000$ & 12 & 24 \\
Liveability $>95 \%$ & 36 & 72 \\
Average period of rearing $<5$ & 40 & 80 \\
(cycle/year) & & \\
Gross income (Rp.) & & \\
$\quad$ Low $(<25$ million) & 17 & 34 \\
$\quad$ Medium( 25-50 million) & 21 & 42 \\
High (>50 million) & 12 & 24 \\
\hline
\end{tabular}

Source: Primary data analysis who studied contract farming in Indonesia. It was found that the contracts in Lombok resulted in improved returns to capital and left participants better off. However, in Bali the contract did not increase returns to capital but did confer other benefits.

\section{Performance Variables}

Performance variables shown in Table 3 explained that contract farmers have been successful in implementing the farm management provided by the integrator. Relatively low mortality (5.10 \pm 2.6$)$, higher body weight $(2.300 \pm 330 \mathrm{~g})$ and low FCR $(1.652 \pm 0.91)$ at relatively shorther marketing age $(40.2 \pm 3.3)$ as expected, demonstrated that the integrators are responsible for all production inputs and "on-farm" processes. PEI shown in this study was also higher than achieved by Schmidt (2008). Broilers at $44 \mathrm{~d}$ of age had 271 and 250 PEI with flock weight 2306 and $2229 \mathrm{~g}$ when reared on 12 and 15 birds $/ \mathrm{m}^{2}$ respectively. These present performance reflected as a response to the reasonable quality of the commercial feed (Table 4). The chemical composition of both starter and finisher diets delivered and used by the contract farmers were parallel with the nutrient requirement particularly crude protein for broilers according to some literatures (Corzo et al., 2005; Nadeem et al, 2005; Gutierrez et al., 2008; Hosseini et al., 2009).

Another important contributing factor for the performance reported in this study is that the availability of the technical service provided by the integrators. This helps the beginner farmers in handling technical factors which can improve their skills gradually. According to Wicker (2001), the poultry industry has been successful in adopting new technology to improve its efficiency in order to meet consumer demand. Conversely, in many developing countries such as in Indonesia, extension activities for small farmers can play a vital role in improving the poultry farming practices particularly but this service is lacking (Mohsin et al., 2008).

\section{SWOT Analysis}

Strength of Contract Farming. Contract in broiler production means agreement between farmers and integrators that specify conditions of producing and marketing (Begum, 2005). This present study showed that contract

Table 3. Performance variables of the broiler contract farming system in Lombok, NTB, June-November $2009(n=50)$

\begin{tabular}{lcc}
\hline \multicolumn{1}{c}{ Variables } & Performance \\
\hline Feed conversion rasio & $1.65 \pm$ & 0.91 \\
Performance index & $349.80 \pm$ & 51.00 \\
Mortality $(\%)$ & $5.10 \pm$ & 2.60 \\
Body weight at marketing $(\mathrm{g})$ & $2300.00 \pm 330.00$ \\
Period of rearing (day) & $40.20 \pm$ & 3.30 \\
Bird density $\left(\mathrm{m}^{2} / \mathrm{bird}\right)$ & $0.13 \pm$ & 0.05 \\
\hline
\end{tabular}

Source: Primary data analysis 
Table 4. Chemical composition (\%) of starter and finisher commercial diet used by the broiler contract farmers in Lombok, NTB, June-November 2009 ( $\mathrm{n}=50)$

\begin{tabular}{lrr}
\hline \multirow{2}{*}{ Nutrient } & \multicolumn{2}{c}{ Diet } \\
\cline { 2 - 3 } & \multicolumn{1}{c}{ Starter } & \multicolumn{1}{c}{ Finisher } \\
\hline Crude protein & $20.78 \pm 2.87$ & $16.72 \pm 1.31$ \\
Crude fiber & $3.42 \pm 0.21$ & $3.73 \pm 0.27$ \\
Crude fat & $3.69 \pm 0.74$ & $5.50 \pm 0.61$ \\
Water & $12.19 \pm 0.58$ & $11.60 \pm 0.50$ \\
Ash & $10.73 \pm 5.76$ & $8.96 \pm 1.04$ \\
\hline
\end{tabular}

Note: Analysed according to AOAC (1976)

farmers have merits and it was as a choice by almost all potential farmers due to (1) risk sharing $(27.6 \%)$, financial credits $(25.8 \%)$, and the guarantee of marketing $(23.3 \%)$ (Table 5). Many studies of contract farming have emphasized on risk reduction as a main incentive for farmers to enter into contracts or lack of capital (Begum, 2005). Price risk is one important contributor to revenue variability. In case of price risk, broilers are perishable when farmer failed to sell at proper time, great losses are faced. Therefore, the biological nature of broilers is the main factors encouraging the instability in price.
Moreover, broilers as agricultural products need proper handling and storage facilities. For these reasons, farmers want to sell out the products immediately to avoid the losses and price fluctuation in the poultry market.

Last experiences (economic crisis in 1998) are good lesson for independent farmers who decided to go to the contract system. Independent farmers with limited capital were unable to compete with the larger company due to no market for independent farmers, less efficient and high risk. As mentioned that the primary reason to joint with the contract system was risk sharing and some farmers studied here were the former self funding farmers. According to FAO (2005), vertical integration in developing countries emerged due to the development of demand in poultry and pigs. Industry orientation its self needs intensive investment (FAO, 2005) and need good organization system (Çinar et al., 2003). Another benefit of the contract farmer is that it can also provide improvements in risk management, increased family employment opportunities and, indirectly, empowerment of women and development of a successful commercial culture (Patrick, 2004).

Weaknesses of Contract Farming. In the present study found some weaknesses of the contract farming system (Figure 2). When looking at the contract payment, contract document, and some clausal agreement, it seemed

\begin{tabular}{|c|c|c|}
\hline $\begin{array}{l}\text { Internal } \\
\text { factors }\end{array}$ & $\begin{array}{l}\text { Opportunities }(\mathbf{O}) \\
\text { 1. The products relatively cheap } \\
\text { sources of animal protein. } \\
\text { 2. No constraints to all religion. } \\
\text { 3. An increase in population as well as } \\
\text { the local government's target to } \\
\text { improve the human development } \\
\text { index, the more available animal } \\
\text { products to young people. } \\
\text { 4. Good in buying power. } \\
\text { 5. Tourist destination. }\end{array}$ & $\begin{array}{l}\text { Threats (T) } \\
\text { 1. Recent national avian influenza (AI) } \\
\text { outbreak. } \\
\text { 2. Local birds which have particular } \\
\text { markets and local foods such as } \\
\text { Taliwang cuisine. } \\
\text { 3. Importation from outside Lombok } \\
\text { with low cost. } \\
\text { 4. Low competition between } \\
\text { integrators. } \\
\text { 5. A pressure from surrounding } \\
\text { community was emerging due to } \\
\text { the manure handling. }\end{array}$ \\
\hline $\begin{array}{l}\text { Strengths (S) } \\
\text { 1. Risk sharing. } \\
\text { 2. Providing financial credits. } \\
\text { 3. The guarantee of marketing. } \\
\text { 4. Improvements in risk management } \\
\text { 5. Increased family employment } \\
\text { opportunities and empowerment } \\
\text { of women. } \\
\text { 6. Development of a successful } \\
\text { commercial culture. }\end{array}$ & $\begin{array}{l}\text { SO Strategies } \\
\text { 1. Improvement of the financial } \\
\text { consideration such as better } \\
\text { knowledge in factors affecting cash } \\
\text { flow and profitability for broiler } \\
\text { production. } \\
\text { 2. Improvement in farmer's knowledge } \\
\text { in understanding their right and } \\
\text { obligatory. } \\
\text { 3. Protein campaign. } \\
\text { 4. Encouraging retail growth. }\end{array}$ & $\begin{array}{l}\text { ST Strategies } \\
\text { 1. Improving the good practices in } \\
\text { animal health which reduce the risk } \\
\text { of outbreak disease. } \\
\text { 2. Introducing new policies for } \\
\text { manure disposal. } \\
\text { 3. Inviting the new investors as } \\
\text { integrators. } \\
\text { 4. Inviting investors to build the feed } \\
\text { mill and or breeding farms. }\end{array}$ \\
\hline $\begin{array}{l}\text { Weaknesses (W) } \\
\text { 1. Contract document kept by the } \\
\text { firm. } \\
\text { 2. Unclear incentive and calculation. } \\
\text { 3. Unclear payment systems. } \\
\text { 4. No fixed schedule to market. }\end{array}$ & $\begin{array}{l}\text { WO Strategies } \\
\text { 1. Intensive training of farmers before } \\
\text { entering in the contract system in } \\
\text { terms of the systems itself, incentive, } \\
\text { and payment system. }\end{array}$ & $\begin{array}{l}\text { WT Strategies } \\
\text { 1. Encouraging farmers to expand the } \\
\text { chicken houses with good manure } \\
\text { handling in selected areas. }\end{array}$ \\
\hline
\end{tabular}


Table 5. Motivating factors of broiler farmers to enter the contract scheme in Lombok, NTB, June-November 2009 $(\mathrm{n}=50)$

\begin{tabular}{lcr}
\hline \multicolumn{1}{c}{ Reasons } & $\begin{array}{c}\text { No of } \\
\text { respondents }\end{array}$ & $\%$ \\
\hline Lack of capital & 42 & 25.8 \\
Additional income & 14 & 8.6 \\
Risk reduction/risk sharing & 45 & 27.6 \\
Marketing guarantee & 38 & 23.3 \\
Facilities provided by the integrator & 23 & 14.1 \\
$\begin{array}{l}\text { Using the available housing (ex } \\
\text {-independent) }\end{array}$ & 1 & 0.6 \\
\hline
\end{tabular}

Note: Multiple answer

Source: Primary data analysis

that farmers were on a weak position. For instance, the contract document was kept by the firm, the costs of inputs were known when payments are made, farmers did not know how to calculate the incentive when available, and sometimes there is no fixed schedule to market the products. According to Saptana (2006), contract farming in poultry commodities in factual operation, farmers are labor who is paid in monthly basis even though there is right on shed. This is due to differences in 'sharing' in contributing on production costs. There is evidence, however, that contract farming may have a negative effect on the welfare of smallholders. A number of authors express concern that contractors favor larger farmers and hence poorer farmers may be left out of the development process (Singh, 2002). Other hazards of contract farming are the potential for 'capture' of smallholders within contracts (Patrick, 2004), negative social effects of the 'cash economy', narrowing of local markets as contracted production squeezes out local food production, deteriorating contract terms as contracts mature and general concerns about how multi-national corporations behave in developing countries (Singh, 2002).

Opportunities. Demand of poultry products is predicted to increase as a result of higher income, relatively cheap sources of animal protein, and no constraints to all religion. In addition, an increase in population as well as the local government's target to improve the human development index, the more available animal products to young people was needed. In the province of NTB, human development index was the second lowest of 33 provinces in Indonesia which relates to the health and education. However, buying power of people was higher (60.99) than the national level (60.39) recoded in 2006 (Journal Lombok, 2008). Thus, this contradictive condition could be something misleading on understanding the importance of animal protein sources. Therefore, protein campaign, disseminasion or socialization on aspects relating to improve the health level in particular would absorb the animal products, which is a good way to endorse the poultry development in this region. As a tourist destination after Bali, Lombok-NTB will be more attractive to travelers both local and foreign people to come. The growth of modem retail such as supermarket seems continued which had positive effects on increasing growth in the poultry industry.

Threats. There are some threats for poultry developments. Recent national avian influenza (AI) outbreak which killed thousands birds and leads to a reduction in demand of poultry products as one of some consequences. This issue also influenced the demand of the poultry products in Lombok in 2007, even though this outbreak happened nationally. Local birds which have particular markets and local foods such as Taliwang cuisine (Lombok food) are other challenges. The demand on local birds to fulfill this sort of food has not been met. Unfortunately, the alternative substitution of this poultry meat for Taliwang was male layers not the broilers. Also importation from outside Lombok with low cost producers sometimes happens and when this continues, is predicted to impair the further development. In addition, low competition between integrators due to the sponsors is dominated only by two integrators, will easily affect the price stability for both the production factors and the live products or carcass. For particular months such as Ramadhan and Maulud in 2009, as comparison, the price for carcass in West Lombok was Rp. $34.000,-/ \mathrm{kg}$ whereas in Java at the same time was only Rp. 24.000,--.

In regard to the negative impact on environment, a pressure from surrounding community was emerging due to the manure handling. Both odor and flies are the main cause of complains. These problems seemed more serious in West Lombok than Central Lombok and East Lombok due to different population between regions.

Strategies. Although contract farmers are currently satisfied with the income and the company's role, no matter some of the term and condition were not met, there is still need for improvement through developing understanding in various risks which would affect income and margin. Improvement of the financial consideration such as better knowledge in factors affecting cash flow and profitability for broiler production are important. At the same time, farmer's knowledge in their right and obligatory should be more reasonable.

Improving the good practices in animal health which reduce the risk of outbreak disease to the farmers by both the local government and the firms would minimize the loss.

Disposal of manure from poultry production may be not applicable as adopted in manure from ruminants which produce biofuel. Thus, it would be worthwhile to introduce new policies for manure disposal. This will be relevant on developing region for increasing quota of production (Çinar et al., 2003) to fulfill the increasing demand in years to come. .

In regard to avoid the monopoly business, it would be preferable to open and offer new investors in the same business. If possible, local government encourage the new investors to build a new feed mill and breeding farm in Lombok to solve problems relating to its dependency on outside Lombok which sometimes affect the price stability. 


\section{Perception of Contract Poultry Farmers to Syariah Bank}

The term of Syariah, in general, have been wellknown by the farmers even though they were not Moslem. As shown in Table 6, fair in profit and low interest were dominant meaning of Syariah Bank. However, the contract farmers seemed reluctant to work with Syariah. Thus, partnership as introduced by Sutawi (2006) as a capital provider in developing the business have not been considered as a new structure of broiler production contract that may be much beneficial to them. Although no clear reasons, it could be due to the current contract system have offered improved returns as reported by Patrick (2004). As mentioned that the first important reason for joining in the contract system is risk sharing not capital needs.

Table 6. Perception on Syariah Bank by the broiler contract farmers in Lombok, NTB, June-November 2009 ( $n=50)$

\begin{tabular}{lcc}
\hline \multicolumn{1}{c}{ Entry } & $\begin{array}{c}\text { No of } \\
\text { respondents }\end{array}$ & $\%$ \\
\hline Familiar with term of Syariah & & \\
Outstanding of Syariah & & \\
Good in services & 40 & 80 \\
Fair in profit & 45 & 90 \\
Low interest & 45 & 90 \\
Willing working with & 7 & 14 \\
\hline
\end{tabular}

Source: Primary data analysis

\section{Government Involvement for Further Development}

As mentioned that most contract farmers satisfied by the scheme, therefore a government regulations is needed to specifically focus on factors used in ranking farmers and determining performance payments. In fact, there were three payments of margin by the integrator, $30 \%: 70 \%$; $40 \%: 60 \%$ or $50 \%: 50 \%$, the ratio between farmers and integrators. However, the reasons for these different payments were unclear. No concrete regulatory actions have been taken so far by the government. Although no literature addressing the theoretical rationale for government regulation of poultry contracts it was argued that by requiring farmers to make large specific investments in chicken houses in selected areas, integrators can increase farmer incentives without increasing farmer compensation since the risk of losing the investment will increase a farmer's fear of low performance (Vukina, 2001). Another involvement, if possible, of the local government is to offer intensive training in order to understand correctly how does the system work?.

\section{CONCLUSION}

Contract broiler production has a great contribution on farmer's income and farmers were satisfied by the integrators as a creditor. Dissatisfactions were on bonus determination, communication, and a number of other operational issues. Risk sharing was the dominant reason to join the system. The different ratio on margins between the contract farmers and creditors were apparent without clear reasons. Performance parameter measured was as an expectation, suggesting feed quality and management aspects were well implemented. In respect to Syariah bank, its outstanding was well understood but it has not been attractive to the contract farmers.

Encouraging the growth of poultry industry for incoming years is needed to provide the animal protein sources by involvement of the local government and looking for the new potential region and legislation on maintaining environment. New investors should be encouraged to overcome instability price that sometimes happen.

\section{ACKNOWLEDGEMENT}

This work was supported by Competitive Grant of Nasional Strategy - DIPA University of Mataram Year 2009 under the contract number: 0234.0/02304.2/XXI/2009, 31 December 2008. We thank Research Centre of Unram for arranging the proposal and report. We would like also to thank Supeno, Kasri and Ade Majaputra for data collection.

\section{REFERENCES}

AOAC. 1970. Official Methods of Analysis, $11^{\text {th }}$ Ed. Association of Official Analysis Chemist, Washington, DC.

Aftab, U. 2009. Response of broiler to practical diets with different metabolizable energy and balanced protein concentration. Rev. Bras. Cienc Avic. 11:169-173. doi: 10.1590/S1516-635X2009000300005

Badan Ketahanan Pangan (BKP). 2008. Situasi konsumsi pangan Provinsi NTB 2008. http://bkp.ntbprov.go.id/web/ content/blogcategory/43/53/in/ (15 December 2008)

Begum , I.A. 2005. An assessment of vertically contract poultry farming: A case study in Bangladesh. Intern. J. Poult. Sci. 4:167-176

Çinar, H., A. Demir, Ş. Kalanlar, B. Taskaya, \& S. Berkum. 2003. Turkish Poultry Meat Sector Analysis. www.lei. wur.nl/NR/rdonlyres/.../TurkishPoultryMeatSectorAnalys is.pdf (15 April 2010)

Corzo, A. M. T. Kidd, D. J. Burnham, E. R. Miller, S. L. Branton, \& R. Gonzalez-Esquerra. 2005. Dietary amino acid density effects on growth and carcass of broilers differing in strain cross and sex. J. Appl. Poult. Res. 14:1-9.

Dozier, W. A., M. T. Kidd, A. Corzo, P. R. Owensc, \& S. L. Branton. 2008. Live performance and environmental impact of broiler chickens fed diets varying in amino acids and phytase. Anim. Feed Sci. Technol. 141: 92-103.

Eaton, C. \& A. W. Shepherd. 2001. Contract farming partnerships for growth. FAO Agricultural Service Bulletin No. 145 .

FAO. 2005. Some issue associated with the livestock industries of the Asia-Pacific region. http://www.fao.org/docrep/005/ AC448E/ac448e05.htm (5 December 2009)

Gutierrez, O., N. Surbakti, A. Haq, J. B. Carey, \& C. A. Bailey. 2008. Effect of continuous multiphase feeding schedules on nitrogen excretion and broiler performance. J. Appl. Poult. Res. 17:463-470. doi:10.3382/japr.2008-00015

Goodwin, Jr. H. L. , B. L. Ahrendsen, T. L. Barton, \& J. H. Denton. 2005. Estimated returns for contract broiler production in Arkansas, Missouri, and Oklahoma: Historical 
and Future Perspectives. J. Appl. Poult. Res. 14:106-115.

Hosseini, S. M., S. M. Akbary, N. Maheri-Sis, \& A. M. Aghsaghali. 2009. The effect of using excess lysine on the performance and slaughter characteristics of broiler chickens. Res. J. Biol. Sci. 4:143-147.

Jurnal Lombok. 2008. Daya beli tinggi, tapi pendidikan dan kesehatan NTB rendah. www.beritadaerah.com/news. php?pg=berita_bali\&id...sub (20 October 2008).

Mohsin, A. Q., R. Riaz, S. Asad, \& A. Mushtaq. 2008. Profitability analysis of broiler production in Rawalpindi District. Pakist. J. Agri. Sci. 45: 514-519.

Nadeem, M. A., A. H. Gilani, A. G. Khan, \& M. U. Nisa. 2005. Assessment of dietary requirement of broiler chicks for available lysine during summer. Int. J. Agri. Biol. 7:995-998.

Patrick, I. 2004. Contract farming in Indonesia: Smallholders and agribusiness working together. Australian Centre for International Agricultural Research, Canberra. http:// aciar.gov.au/system/files/node/533/tr54.pdf (20 November 2009)

Priyono, B. S., N. Nufus, \& K. Dessy. 2004. Performan pelaksanaan kemitraan PT.Primatama Karya Persada dengan peternak ayam ras pedaging di kota Bengkulu. J. Ilmuilmu Pert. Ind. 6:111-115.

Saptana. 2006. Keunggulan komparatif -kompetitif dan strategi kemitraan. Dampak Krisis. www.akademik.unsri. co.id/download/journal/files/udejournal/(5) (20 November 2008)

Schmidt, G. S. 2008. Evaluation of the technical and economic impacts of high-density broiler production in an integrated system. Rev. Bras. Cienc Avic.10:149-152. doi: 10.1590/S1516-635X2008000300002

Siagian, S. H. 2001. Peranan usaha peternakan dalam pengembangan wilayah. Tesis. Program Pasca Sarjana Universitas Sumatera Utara, Medan.

Simmons, P., P. Winters, \& I. Patrick. 2005. An analysis of contract farming in East Java, Bali and Lombok, Indonesia. Agricultural Economics, 33, Suppl.513-525

Singh, S. 2002. Contracting out solution: Political economy of contract farming at the Indian Punjab: World Dev. 30:1621-1638.

Sutawi. 2006. Model agribisnis Syariah. Poultry Indonesia, September page 45.

Tatlidil, F. F. \& D. Aktũrk. 2004. Comparative analysis of contract and non contract farming model in tomato production. J. Agronom. 3:305-310.

Vukina, T. 2001. Vertical integration and contracting in the U.S. poultry sector. J. Food Distr. Res. July: 29-38. ageconsearch. umn.edu/bitstream/27819/1/32020029.pdf

Wicker, D. I. 2001. Obstacles and challenges in implementing new technologies in the poultry industry. J. Appl. Poult. Res. 10:303-305 